\title{
Mammary-tissue amino acid transport systems
}

\author{
BY D. B. SHENNAN, I. D. MILLAR AND D. T. CALVERT \\ Hannah Research Institute, Ayr KA6 5HL
}

\begin{abstract}
Amino acid movement across cell membranes is mediated by a variety of transport systems. These pathways have been extensively studied and characterized in a large array of cell types and include both $\mathrm{Na}^{+}$-dependent and $\mathrm{Na}^{+}$-independent carriers. In addition, recent work suggests that channels may also play a role in amino acid transport. The objective of the present paper is to review current knowledge about amino acid transport mechanisms in lactating mammary cells. Information available about mammary amino acid transporters and their regulation is limited compared with such mechanisms in other tissues. Nevertheless, a picture is emerging of the discrete transport systems involved and it is apparent that several of these mechanisms have unique kinetic and regulatory properties.

The lactating mammary gland has a large demand for amino acids to meet the requirements of milk-protein synthesis. For example, the mammary tissue of a cow secreting 35 litres milk/d with a protein content of $32 \mathrm{~g} / \mathrm{l}$ needs over $1 \mathrm{~kg}$ amino acids/d to sustain milk-protein synthesis. Amino acids are extracted from blood by specific transport systems situated in the mammary cells, as reflected in the large arterio-venous amino acid concentration differences across the gland (for example, see Metcalf et al. 1991; Guinard \& Rulquin, 1994). Identification and characterization of the mechanisms involved in the transport of amino acids by the mammary gland is required if we are to understand fully the process of milk-protein synthesis and secretion. The transport of certain amino acids by mammary secretory cells could be rate-limiting for milk-protein synthesis (Mepham, 1982), therefore a detailed knowledge of the individual transport systems with respect to their kinetics, substrate specificity and regulation may help develop strategies aimed at manipulating the protein content of milk. In this connection many studies have attempted to identify rate-limiting amino acids by way of manipulating plasma amino acid concentrations. This approach has often met with little success and probably reflects the lack of knowledge about the substrate specificity and kinetics of mammary amino acid transporters.
\end{abstract}

\section{EXPERIMENTAL TECHNIQUES IN THE STUDY OF AMINO ACID TRANSPORT BY THE MAMMARY TISSUE}

The functional unit of the mammary gland is the secretory alveolus which comprises a single layer of secretory cells surrounding a hollow lumen (Hollmann, 1974). As with other epithelial cells, those of the mammary gland are polarized and, thus, are capable of vectorial solute transport (Linzell \& Peaker, 1971; Shennan, 1990). The transport properties of the 'blood-facing' aspect of the secretory cells are the most important as this is the major, if not only, site of amino acid uptake. This is a situation analogous to that of other secretory epithelia such as the pancreas and salivary glands.

Unfortunately, the structure of the mammary gland makes it difficult to study vectorial amino acid transport (Shennan, 1990). The gland cannot, as with some epithelia, be mounted in Ussing chambers to gain separate access to the individual aspects of the secretory epithelium. At present there are no techniques available for the preparation of isolated basolateral-membrane vesicles which would be invaluable for membrane transport 
studies. There is, however, a method for the isolation of mammary secretory-cell apicalmembrane vesicles from milk (Shennan, 1992) which can be used to investigate whether the apical membrane expresses specific amino acid transport systems. Mammary tissue explants and the perfused mammary gland are good experimental models for studying amino acid transport by lactating mammary cells. Explants are easy to prepare and do not require biochemical treatments (i.e. collagenase (EC 3.4.24.3) digestion) which could ultimately alter the transport properties of the secretory cells (see Blatchford et al. 1995). Another major advantage of explants is that the normal glandular architecture remains intact, which may be crucial for the normal functioning of certain transport systems. The major drawbacks of explants are that (a) they have a mixed cell population and (b) it is believed to be difficult to separate transport events occurring at the apical and basolateral poles of the epithelium. However, explants taken from animals during peak lactation mostly comprise $(>85 \%)$ secretory cells and the acinar structure of the gland determines that the majority of the surface area of explants exposed to an incubation medium will be the basolateral membranes of secretory cells. In addition, there is the strong possibility that the ducts of mammary explants become sealed, further isolating the apical membranes of the secretory cells from the incubation medium. Thus, explants offer a convenient means of studying the transport of amino acids across the basolateral aspect of the mammary epithelium. Isolated mammary acini have also been used to study solute transport. Although acini are more representative of secretory cells than explants, the apical aspect of the acini becomes exposed to the incubation medium, thus making it difficult to discern whether transport is occurring at the apical or basolateral surface of the secretory cell. The perfused lactating mammary gland allows transport across the 'blood-facing' aspect of the mammary epithelium to be studied under almost physiological conditions. The perfused mammary preparation used in conjunction with a rapid, paired-tracer dilution technique (Yudilevich \& Mann, 1982) has proved useful in the kinetic characterization of mammary amino acid transporters (Mepham et al. 1985; Calvert \& Shennan, 1996; Millar et al. 1996a). The main disadvantage of this experimental method is that it is technically demanding and requires considerable operator expertise.

Cultured mammary cells have been used to examine amino acid transport (see Shennan, 1990). However, care must be exercised when extrapolating findings used with cultured cells to that of the intact tissue. For example, the apical membranes of cultured cells are normally exposed to incubation media which have compositions unlike that of milk (no lactose, higher ionic strength). This will lead to changes in the electrical potential of the mammary cells, which in turn will affect the activity of electrogenic transport systems. Mammary cells cultured on a reconstituted basement membrane do, however, form acinar structures enclosing a hollow lumen (Barcellos-Hoff et al. 1989; Chen \& Bissell, 1989; Hurley et al. 1994; Blatchford et al. 1995). These acini, termed mammospheres, appear to be polarized and are capable of secreting protein in a vectorial fashion (Blatchford et al. 1995). Mammospheres, therefore, may be a useful cultured-cell model to study mammary amino acid transport.

\section{SODIUM-DEPENDENT AMINO ACID TRANSPORT SYSTEMS}

The mammary epithelium is able to generate large transepithelial amino acid concentration gradients (plasma $>$ milk) as well as maintaining large concentration gradients for most amino acids across the apical and basolateral membranes (intracellular > extracellular; Table 1). An exception to this is the finding that the mammary epithelium of some species, notably man, is able to concentrate glutamate and taurine in milk with respect to plasma. 
Table 1. Amino acid concentration in bovine plasma, milk and mammary tissue (Shennan, Remsbury and Knight, unpublished results)

\begin{tabular}{lccc}
\hline \hline Amino acid & Plasma $(\mathrm{mmol} / \mathrm{l})$ & Milk $(\mathrm{mmol} / \mathrm{l})$ & Mammary $(\mathrm{mmol} / \mathrm{kg}$ intracellular water) \\
\hline Glutamate & 0.16 & 0.18 & 10.54 \\
Taurine & 0.07 & 0.06 & 6.98 \\
Glycine & 0.57 & 0.05 & 5.49 \\
Aspartate & 0.02 & 0.02 & 2.73 \\
Alanine & 0.48 & 0.04 & 2.62 \\
Glutamine & 0.28 & 0.06 & 1.54 \\
Serine & 0.22 & 0.02 & 0.77 \\
Arginine & 0.16 & 0.02 & 0.90 \\
Valine & 0.50 & 0.03 & 0.54 \\
Asparagine & 0.20 & 0.01 & 0.29 \\
Isoleucine & 0.32 & 0.01 & 0.43 \\
Leucine & 0.31 & 0.01 & 0.29 \\
Methionine & 0.05 & $\mathrm{Nd}$ & 0.23 \\
Lysine & 0.21 & 0.02 & 0.16 \\
Tyrosine & 0.09 & 0.01 & 0.91 \\
Phenylalanine & 0.09 & 0.01 & 0.47 \\
Threonine & 0.29 & 0.31 & 2.39 \\
\hline \hline
\end{tabular}

Nd, not detected.

This suggests that amino acids cannot readily pass across the tight junctions between mammary secretory cells. The observation that mammary cells are capable of concentrating amino acids with respect to plasma indicates that a source of energy is required during the transport process. One such source is the $\mathrm{Na}^{+}$gradient maintained by the action of the $\mathrm{Na}^{+}-\mathrm{K}^{+}$pump. It has been known for many years that the energy required for amino acid uptake into most cells can be supplied by the $\mathrm{Na}^{+}$gradient; the mammary gland is no exception. Thus, $\mathrm{Na}^{+}$-dependent systems for the transport of neutral (systems $\mathrm{A}$ and $\mathrm{ASC}$ ), anionic (system $\mathrm{X}^{-}{ }_{\mathrm{AG}}$ ) and $\beta$-amino acids have been identified in mammary tissue.

System A, which is characterized by its tolerance of $\mathrm{N}$-methylated substrates (i.e. methyl-aminoisobutyric acid; MeAIB), has been described in mouse, rat and bovine mammary tissue (Neville et al. 1980; Baumrucker, 1985; Shennan \& McNeillie, 1994a). The mammary A system, like that described previously, appears to prefer short straightchain neutral amino acids as substrates (Neville et al. 1980). The activity of this $\mathrm{Na}^{+}-$ dependent system may be responsible for the intracellular accumulation of amino acids such as alanine and glycine by mammary tissue (Table 1). System ASC, which unlike system A cannot transport $\mathrm{N}$-methylated amino acids, has been identified in bovine (where it co-exists with system A) and guinea-pig mammary tissue (Baumrucker, 1985; Mepham et al. 1985) but appears to be absent in rat and mouse mammary tissue (Neville et al. 1980; Shennan \& McNeillie, 1994a). This variation in the distribution of the $\mathrm{Na}^{+}$-dependent systems occurs in the placenta as well as in the mammary gland (Yudilevich \& Sweiry, 1985).

Glutamate is the most abundant amino acid in milk protein. In some species the extraction of glutamate from plasma by the lactating mammary gland can exceed $70 \%$ of the arterial load, and glutamate uptake can, in some cases, be the highest of all the nonessential amino acids (for example, see Guinard \& Rulquin, 1995). Glutamate uptake based on arterio-venous concentration differences may underestimate the true uptake by the mammary gland. Glutathione, a glutamate-containing tripeptide, may be an important 
source of glutamate as a consequence of the activity of $\gamma$-glutamyl-transpeptidase, an enzyme which is present in relatively high levels in mammary tissue (Baumrucker et al. 1981; Pocius et al. 1981). Despite the importance of glutamate to the mammary gland, it is only recently that the transport of anionic amino acids has been investigated (Millar et al. 1996a). Glutamate transport by rat mammary explants and the perfused lactating rat mammary gland is almost entirely dependent upon $\mathrm{Na}^{+}$ions; choline, $\mathrm{Li}^{+}$and N-methyl-Dglucamine ions are not capable of substituting for $\mathrm{Na}^{+}$. This finding taken together with the observation that glutamate efflux from mammary explants can be stimulated by reversing the transmembrane $\mathrm{Na}^{+}$gradient suggested that the $\mathrm{Na}^{+}$-dependent moiety represents $\left(\mathrm{Na}^{+}\right.$-glutamate) cotransport. The cotransporter is a high-affinity system which interacts with anionic, but not neutral and cationic, amino acids. The $K_{m}$ values of glutamate uptake found with rat mammary explants and the perfused rat mammary gland are respectively 118 and $18 \mu \mathrm{M}$; the difference between the two values probably reflects the presence of larger unstirred fluid layers associated with the explants (Barry \& Diamond, 1984). Interestingly, the mammary tissue $\mathrm{Na}^{+}$-dependent anionic transport system does not discriminate between the optical isomers of aspartate but prefers L-glutamate to Dglutamate. Further experiments have revealed that $\mathrm{D}$-aspartate is transported by mammary tissue with characteristics similar to that of L-glutamate transport (Fig. 1). These results strongly suggest that the mammary gland expresses a mechanism which resembles system $\mathrm{X}_{\mathrm{AG}}^{-}$, a transporter which has been described in brain, intestine, kidney and placenta (Kanai et al. 1994). Some of the high-affinity ( $\mathrm{Na}^{+}$-glutamate) cotransporters have been cloned and their primary amino acid sequences have been determined (Kanai \& Hediger, 1992; Pines et al. 1992; Storck et al. 1992). Although the molecular identity of the mammary transporter has not been identified it appears, on the basis of a pharmacological study, that the mammary gland expresses a novel form (Millar et al. 1996b). Thus, glutamate and aspartate uptake by rat mammary tissue is inhibited by dihydrokainate but not aminoadipate (both are L-glutamate analogues): this pharmacological profile is not exhibited by any of the cloned $\left(\mathrm{Na}^{+}-\mathrm{L}\right.$-glutamate) cotransporters. It has also been found that bovine and ovine mammary tissues express a $\left(\mathrm{Na}^{+}\right.$-dependent) anionic amino acid transport system (Millar \& Shennan, unpublished results).

Taurine (2-aminoethanesulfonic acid) is a $\beta$-amino acid which is involved in a large variety of biological functions (Huxtable, 1992). For example, this non-protein amino acid is required for bile salt synthesis, neuro-inhibition, as an intracellular osmolyte and is involved in $\mathrm{Zn}$ and $\mathrm{Ca}$ metabolism. Some animals, including human subjects, have a limited capacity to synthesize taurine and, therefore, require an exogenous supply. The mammary glands of a number of species are capable of concentrating taurine in milk with respect to plasma, and taurine is commonly the most abundant free amino acid in milk (Rassin et al. 1978). Taurine is also present in the milk of species whose young are capable of synthesizing the amino acid, suggesting that milk-derived taurine is important to the sucking neonate. Sturman et al. (1977) found that radiolabelled taurine injected intraperitoneally into rats is transported across the mammary gland into milk suggesting that the transepithelial movement of preformed taurine is important.

The uptake of taurine by lactating rat mammary tissue explants has been examined and is dependent on the presence of extracellular $\mathrm{Na}^{+}$and $\mathrm{Cl}^{-}$in a manner consistent with $\left(\mathrm{Na}^{+}+\mathrm{Cl}^{-}+\right.$taurine) cotransport (Shennan \& McNeillie, 1994b). This transport mechanism is a high-affinity system $\left(K_{m} 43 \mu \mathrm{M}\right)$ which only accepts $\beta$-amino acids (i.e. taurine, $\beta$-alanine, hypotaurine) as substrates. This system is probably situated in the basolateral membranes of mammary secretory cells and is, therefore, responsible for concentrating taurine within mammary cells with respect to plasma. It appears that the 
mammary $\beta$-amino acid cotransport system is kinetically similar to that described in placenta, intestine and kidney (Huxtable, 1992). The mechanism of taurine transport across the apical aspect of the mammary epithelium remains to be determined.

The concentration of taurine in gerbil (Tatera spp.) milk is exceptionally high $(6 \mathrm{mM}$; Rassin et al. 1978). Taurine uptake by gerbil mammary tissue, like that of the rat, is mediated by a high-affinity mechanism $\left(K_{m} 70 \mu \mathrm{M}\right)$ that is $\mathrm{Na}^{+}$-dependent and selective for $\beta$-amino acids (Shennan, 1995). However, an unusual property of taurine uptake by gerbil mammary tissue is that it is not dependent on $\mathrm{Cl}^{-}$. Thus, substituting $\mathrm{Cl}^{-}$with $\mathrm{SCN}^{-}$or $\mathrm{NO}_{3}{ }^{-}$does not reduce taurine accumulation by gerbil mammary tissue explants. However, it is apparent that the gerbil mammary $\mathrm{Na}^{+}$-dependent taurine transporter does require the presence of a permeable anion, as gluconate does not substitute for $\mathrm{Cl}^{-}$. Interestingly, $\mathrm{Cl}^{-}$-independent, $\mathrm{Na}^{+}$-dependent taurine transport has been described in cultured human kidney cells but unlike the mechanism characterized in gerbil mammary tissue it is a low affinity $\left(K_{m} 1 \mathrm{mM}\right)$ system (Jessen, 1994).

\section{SODIUM-INDEPENDENT AMINO ACID TRANSPORT SYSTEMS}

There is good evidence for the presence of the $\mathrm{Na}^{+}$-independent $\mathrm{L}$ system in lactating mammary tissue of several species, i.e. the rat, mouse, guinea-pig and cow (Neville et al. 1980; Baumrucker, 1985; Mepham et al. 1985; Shennan \& McNeillie, 1994a). The uptake of $\alpha$-aminoisobutyric acid (AIB), a non-metabolizable amino acid analogue, by mammary tissue explants isolated from the rat and mouse can be inhibited by 2-aminobicycloheptane-2-carboxylic acid (BCH), a paradigm substrate of the $\mathrm{L}$ system (Neville et al. 1980; Shennan \& McNeillie, 1994a). Based on cis-inhibition studies, it would seem that the mammary L system has a very broad substrate specificity, with the preferred substrates being the branched-chain amino acids plus phenylalanine, tryptophan and methionine. However, system $L$ probably transports most naturally-occurring amino acids and this transport system which has been thoroughly characterized in other tissues appears to act as an exchange mechanism. Accordingly, Baumrucker (1985) has shown that the uptake of cleucine, a specific system L substrate, by bovine mammary explants can be transaccelerated by internal c-leucine. On the other hand, no evidence for the trans-stimulation of AIB efflux via system $L$ from rat mammary tissue was found with phenylalanine and tryptophan, suggesting that there may be mammary tissue variants of the $\mathrm{L}$ mechanism (Shennan \& McNeillie, 1994a).

Cationic amino acid transport by the lactating mammary gland is of interest because, in some species, arginine is taken up in excess of its output in milk (for example, see Clark et al. 1978). Baumrucker (1984) examined cationic amino acid uptake by bovine mammary tissue explants and identified a $\mathrm{Na}^{+}$-independent system which transports lysine and arginine. However, the system responsible for cationic amino acid transport in bovine mammary tissue also appears to react with neutral amino acids. In this connection there is convincing evidence that a $\mathrm{Na}^{+}$-independent cationic amino acid transport system in lactating rat mammary tissue is capable of interacting with a wide variety of neutral amino acids (Shennan et al. 1994b; Calvert \& Shennan, 1996). Thus, a wide range of neutral amino acids, in addition to cationic amino acids, are capable of inhibiting lysine uptake by, and stimulating lysine efflux from, rat mammary tissue explants. Trans-stimulation of lysine efflux by neutral amino acids suggests that neutral amino acids are actually transported by the carrier. The interaction between neutral and cationic amino acids may have important physiological implications, as the transport of lysine and arginine by the 

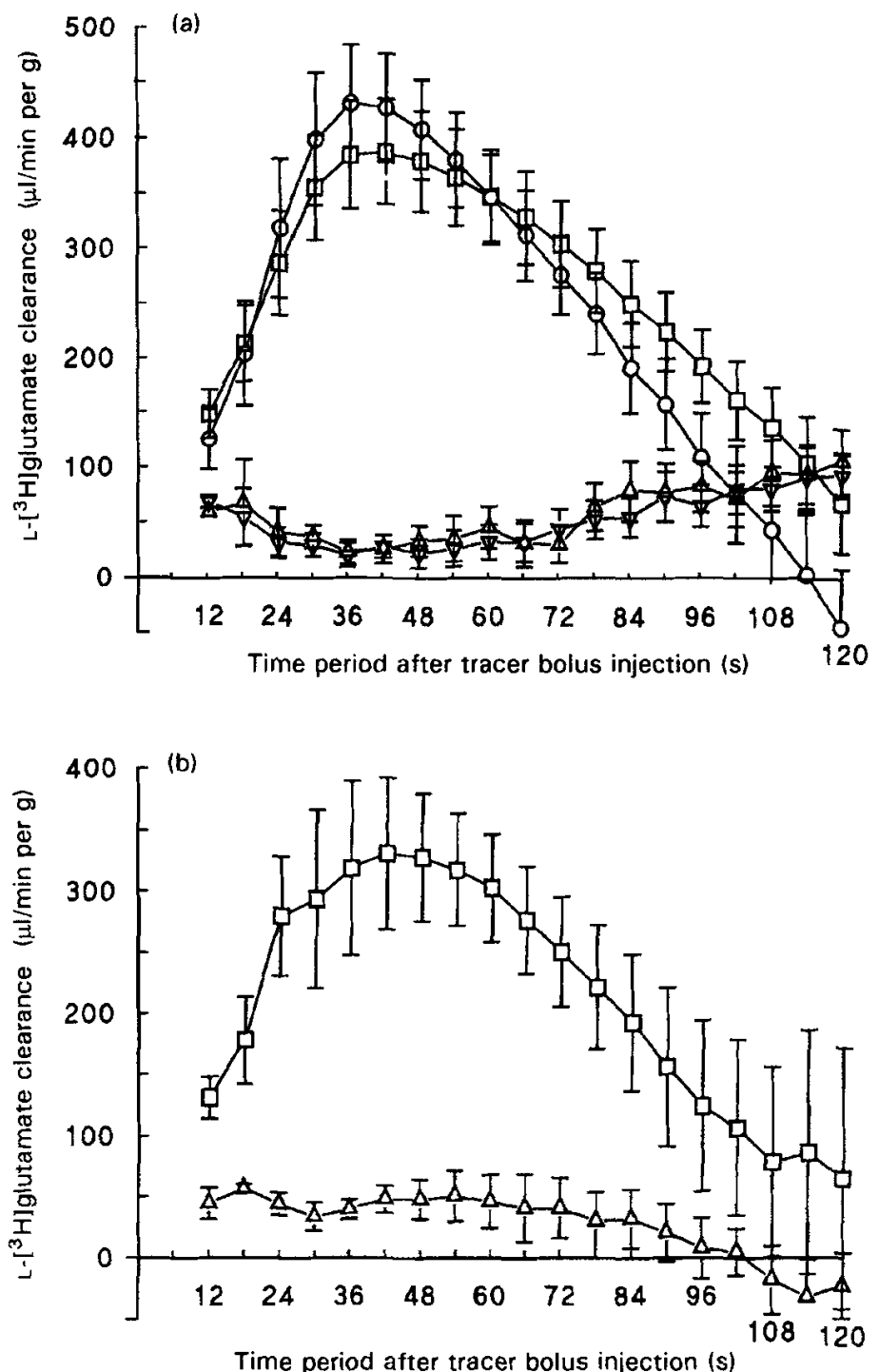

Fig. 1. (a). The effect of D-glutamate $(O)$, L-aspartate $(\nabla)$ and D-aspartate $(\Delta)$, on L-glutamate $(\square)$ clearance by the perfused lactating rat mammary gland. (b), The clearance of L-glutamate by the rat mammary gland in the presence ( $\square$ ) and absence $(\triangle)$ of $\mathrm{Na}^{+}\left(\mathrm{N}\right.$-methyl-D-glucamine ion (NMDG $\left.{ }^{+}\right)$replacement). (c). The effect of L-glutamate $(\nabla)$, Dglutamate $(\triangle)$ and L-aspartate $(O)$ on $D$-aspartate clearance $(\square)$ by the perfused lactating rat mammary gland. (d), The clearance of $D$-aspartate in the presence $(\square)$ and absence $(\Delta)$ of $\mathrm{Na}^{+}$(NMDG ${ }^{+}$replacement). The transport of radiolabelled amino acids by the perfused gland was measured using a rapid, paired-tracer dilution technique using radiolabelled sucrose as the extracellular marker. A bolus $(60 \mu \mathrm{l})$ containing the tracers was injected arterially and venous outflow samples were immediately collected at $6 \mathrm{~s}$ intervals. The unlabelled amino acids, when required, were added to the injectate at a concentration of $50 \mathrm{~mm}$. Values are means with their standard errors represented by vertical bars. (From Millar et al. 1996b; Millar, Calvert and Shennan, unpublished results.) 

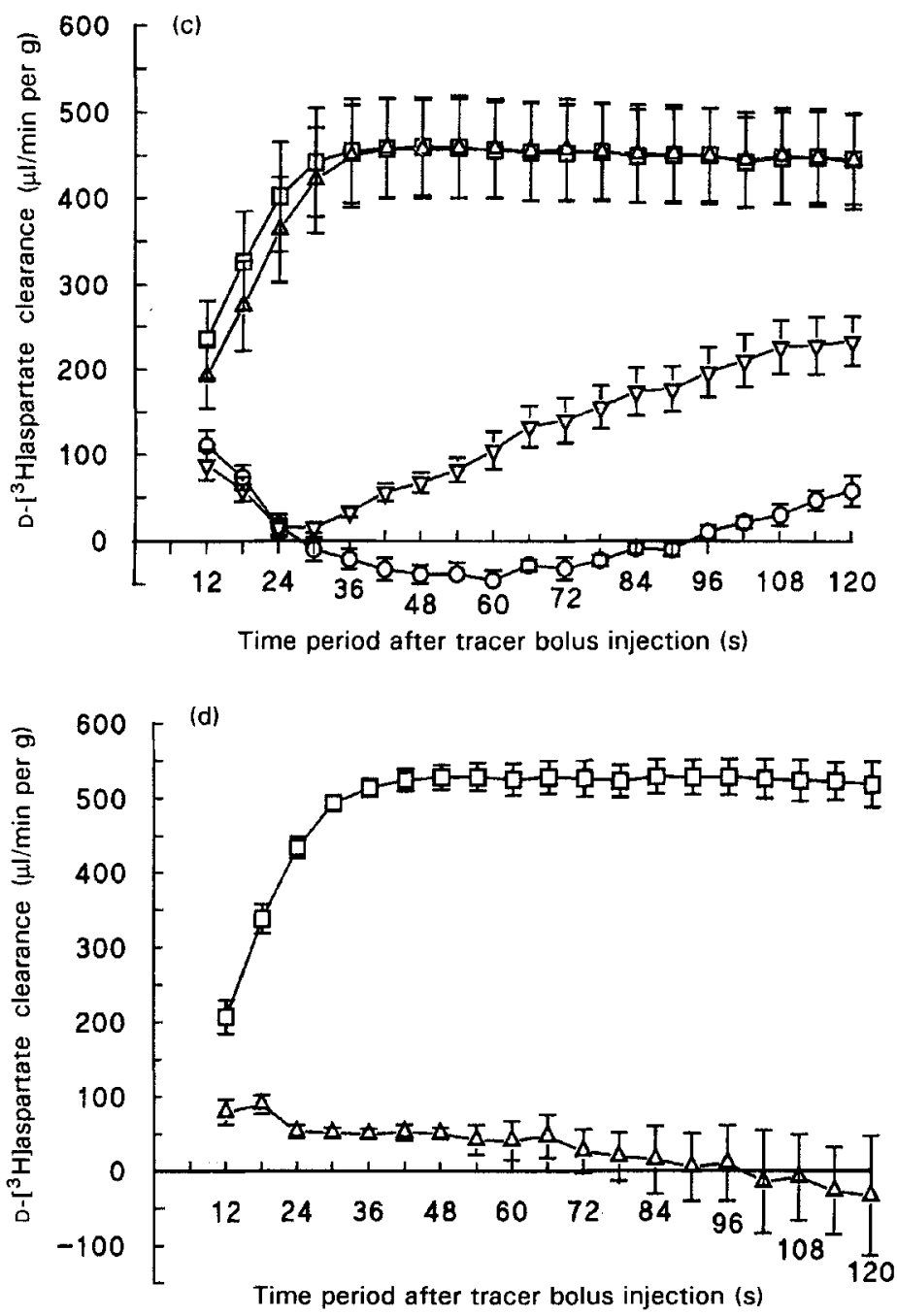

Fig. 1. (c) and (d).

mammary gland may be influenced by the intra- and extracellular concentrations of neutral amino acids. The pattern of selectivity of the mammary cationic amino acid transport system appears to rule out system $\mathrm{y}^{+}$, a transport mechanism which only accepts cationic amino acids as substrates. Furthermore, the finding that lysine transport is not affected by MeAIB and only slightly affected by $\mathrm{BCH}$ respectively rules out a role for systems $\mathrm{A}$ and L. The mammary cationic amino acid transporter which interacts with neutral amino acids, and appears to be situated in the 'blood-facing' aspect of the epithelium (Calvert \& Shennan, 1996), may be related to other cationic amino acid transport mechanisms which have been described in other tissues. For example, a $\mathrm{Na}^{+}$-independent system, termed $\mathrm{b}^{\mathrm{o}}$, which transports neutral and cationic amino acids has been described in blastocysts, kidney, and placental trophoblasts (Van Winkle et al. 1988; Bertran et al. 1992; Furesz et 
al. 1992). In addition, Deves et al. (1992) have identified a system $\left(\mathrm{y}^{+} \mathrm{L}\right)$ which transports both cationic and neutral amino acids in human erythrocytes.

\section{REGULATION OF AMINO ACID TRANSPORT BY PROLACTIN AND MILK STASIS}

Prolactin appears to regulate amino acid transport in the mammary gland. Vina et al. (1981a) found that lactating rats treated with bromocryptine exhibited decreased arteriovenous concentration differences across the mammary gland for all amino acids except aspartate, glutamate and valine. Normal arterio-venous differences for most amino acids were restored by administering exogenous prolactin, suggesting that bromocryptine was exerting its action by inhibiting prolactin secretion from the pituitary and not as a consequence of interfering with some other mechanism. In accordance with the observations of Vina et al. (1981a), recent work has shown that prolactin may be required for the optimal activity of systems $\mathrm{A}$ and $\mathrm{L}$ in the lactating rat mammary gland (Table 2). Thus, mammary tissue taken from lactating rats treated with bromocryptine exhibits a lower capacity for AIB uptake via both MeAIB- and BCH-sensitive pathways compared with tissue taken from untreated animals. The reduction in amino acid transport via system A probably cannot be attributed to a change in the $\mathrm{Na}^{+}$gradient, as bromocryptine treatment had no effect on the activity of the $\mathrm{Na}^{+}-\mathrm{K}^{+}$pump activity in mammary tissue (Shennan \& Madon, 1991). It has been reported that prolactin can stimulate the uptake of AIB by cultured mouse mammary gland cells (Rillema et al. 1992). This stimulation is a consequence of increasing the $V_{\max }$ of transport with no change in the $K_{m}$. The action of the hormone has a latent period of $6 \mathrm{~h}$ and requires ongoing mRNA and protein synthesis. Rillema et al. (1992) did not identify the amino acid transport pathways which were upregulated by prolactin but systems $\mathrm{A}$ and $\mathrm{L}$ are good candidates given the similarity of AIB transport variables between rat and mouse mammary tissue. Prolactin also appears to regulate the transport system responsible for cationic amino acid transport in rat mammary tissue since bromocryptine treatment reduces the arterio-venous concentrations of arginine

Table 2. The effect of bromocryptine treatment on $\alpha$-aminoisobutyric acid (AIB) uptake by lactating rat mammary tissue fragments $\dagger$ (Shennan, unpublished results)

(Mean values with their standard errors for fifteen separate experiments for the untreated (i.e. control) group and seven separate experiments for the bromocryptine-treated group)

\begin{tabular}{llllll}
\hline & \multicolumn{3}{c}{ AIB uptake (mmol/kg cell water) } \\
\cline { 2 - 3 } & \multicolumn{2}{c}{ Untreated } & & \multicolumn{2}{c}{ Bromocryptine-treated } \\
\cline { 2 - 3 } \cline { 5 - 6 } Additions & Mean & SE & & Mean & SE \\
\hline None & 1.31 & 0.11 & & $0.72^{* * *}$ & 0.06 \\
MeAIB & 0.84 & 0.04 & & $0.53^{* *}$ & 0.08 \\
BCH + MeAIB & 0.16 & 0.01 & & $0.21^{*}$ & 0.02 \\
M MeAIB & 0.47 & 0.07 & & $0.19^{* * *}$ & 0.03 \\
$\Delta$ BCH & 0.68 & 0.05 & & $0.32^{* * *}$ & 0.06 \\
\hline \hline
\end{tabular}

MeAIB, methyl-aminoisobutyric acid; $\mathrm{BCH}, 2$-aminobicyclo-heptane-2-carboxylic acid; $\triangle \mathrm{MeAIB}, \Delta \mathrm{BCH}$, change in the uptake due to MeAIB and $\mathrm{BCH}$ respectively.

Mean values were significantly different from those for the untreated group (Student's unpaired $t$ test): $* P<0 \cdot 05$, $* * P<0.01, * * * P<0.001$.

$\dagger$ Rats were treated with bromcryptine for $48 \mathrm{~h}$ before isolating mammary tissue. AIB uptake was measured over $20 \mathrm{~min}$ in tissue suspended in a medium containing $1 \mathrm{~mm}-\mathrm{AIB}, 135 \mathrm{mM}-\mathrm{NaCl}, 5 \mathrm{mM}-\mathrm{KCl}, 2 \mathrm{mM}-\mathrm{CaCl}_{2}, 1 \mathrm{mM}-\mathrm{MgSO}_{4}$, $10 \mathrm{~mm}$-glucose, $10 \mathrm{~mm}$-Tris-N,N-bis[2-hydroxyethyl]-2-aminoethanesulfonic acid, $\mathrm{pH} 7 \cdot 4$. MeAIB and $\mathrm{BCH}$ were used at $30 \mathrm{mM}$ when required. 
and lysine (Vina et al. 1981a). On the other hand, the high affinity $\mathrm{Na}^{+}$-dependent anionic amino acid transport system (Millar et al. 1996b) is not regulated by prolactin, given that aspartate and glutamate extraction by the mammary gland was unaffected by bromocryptine treatment (Vina et al. 1981a). This is further evidence that prolactin is not controlling amino acid transport via system $A$ as a result of reducing the extent of the $\mathrm{Na}^{+}$gradient.

Milk accumulation (i.e. stasis) appears to have a marked effect on amino acid transport by the lactating rat mammary gland. Vina et al. $(1981 b)$ made the interesting observation that premature weaning decreased arterio-venous amino acid concentration differences across the mammary gland. Subsequent experiments by Shennan \& McNeillie (1994c) revealed that the activities of systems $A$ and $L$ are affected by milk stasis. In their experiments, like that of Vina et al. $(1981 b)$, they used rats that were allowed to suckle their young but had the teats sealed on one side to prevent milk removal; therefore, these rats had both normal (i.e. suckled) and weaned glands each having the same blood flow and hormonal environment. Uptake of AIB by explants prepared from the weaned gland was reduced compared with that by explants isolated from the control gland. The reduction in amino acid uptake was attributable to decreased uptake via MeAIB- and BCH-sensitive pathways. Decreased amino acid transport may be a consequence of increased intramammary pressure and/or the accumulation of a milk-borne inhibitor (Wilde \& Peaker, 1990). It is now firmly established that the rate of milk secretion is regulated by an inhibitor (feedback inhibitor of lactation; FIL) in an autocrine fashion. Milk accumulation does, however, lead to a decreased number of prolactin receptors in the rat mammary gland (Hayden \& Smith, 1981). Thus, given that systems A and L are affected by prolactin, it is possible that milk accumulation reduces amino acid transport by lowering the number of prolactin receptors, via a mechanism controlled by FIL, in the basolateral membranes of mammary secretory cells. The observation by Vina et al. $(1981 b)$ that unilateral weaning reduces the arterio-venous concentration differences of anionic and cationic amino acids suggests that milk stasis affects other mechanisms in addition to systems $A$ and $L$. However, milk accumulation must regulate the transport of anionic amino acids via a mechanism independent of prolactin, in view of the finding that bromocryptine treatment did not affect the uptake of glutamate and aspartate by the lactating rat mammary gland (Vina et al. 1981a).

\section{VOLUME-ACTIVATED AMINO ACID TRANSPORT}

Cells, on account of their high permeability to water, rapidly change volume when exposed to anisosmotic media. For example, when cells are placed in an hyposmotic medium they initially behave like perfect osmometers and swell. However, most cells are capable of regulating their volume towards a normal level following swelling. This process, known as a regulatory volume decrease (RVD), depends on a reduction in the total quantity of intracellular osmolytes. It has been established that cell swelling activates the release of ions such as $\mathrm{K}^{+}$and $\mathrm{Cl}^{-}$via pathways such as $\left(\mathrm{K}^{+}+\mathrm{Cl}^{-}\right)$cotransport and separate $\mathrm{K}^{+}$ and $\mathrm{Cl}^{-}$channels (for reviews, see Hoffmann \& Simonsen, 1989; Sarkadi \& Parker, 1991). The movement of ions together with osmotically-obliged water allows the cells to reduce their volume. However, it appears that cell volume regulation, following swelling, also involves amino acids (Chamberlin \& Strange, 1989; Hoffmann \& Simonsen, 1989; Kinne, 1993; Lang et al. 1993). In some cells amino acids are present at such high concentrations that they can be considered as important internal osmolytes. In this connection the mammary gland has a relatively large intracellular amino acid pool which makes a 
significant contribution to the intracellular osmolarity. This taken together with the finding that many amino acids have large intra-to-extracellular concentration gradients means they are ideally placed to be used by mammary cells to regulate volume in response to cell swelling. Accordingly, a hyposmotic shock, and hence cell swelling, increases the efflux of certain amino acids from lactating rat mammary tissue explants (Shennan et al. 1994a). For example, cell swelling increases the release of taurine. Volume-sensitive taurine release occurs immediately after swelling and is a fully reversible process with the increase in efflux being dependent on the extent of cell swelling (Fig. 2(a)). It appears that volumeactivated taurine release inactivates with time (Fig. 2(b)); this may reflect that the mammary explants are volume-regulating. Volume-sensitive taurine efflux can also be stimulated by incubating mammary tissue in an isosmotic buffer which contains a relatively high concentration of urea, suggesting that amino acid efflux is responding to changes in cell volume rather than the external osmolality. The finding that volumesensitive taurine efflux is independent of the transmembrane $\mathrm{Na}^{+}$gradient and is not obligatory dependent on $\mathrm{Cl}^{-}$suggests that it cannot be attributed to $\mathrm{Na}^{+}$-dependent amino acid carriers (e.g. systems $\beta, \mathrm{A}, \mathrm{X}^{-}{ }_{\mathrm{AG}}$ ) operating in reverse mode. $\mathrm{Na}^{+}$-independent amino acid carriers such as system $L$ and the cationic amino acid transporters have also been ruled out as candidates (Shennan et al. 1994a). Volume-sensitive taurine release from the perfused lactating rat mammary gland has also been observed, suggesting that the transport system is situated in the basolateral membranes of the secretory cells (Calvert \& Shennan, unpublished results). This makes physiological sense as it would allow the dam to retain taurine following cell volume regulation. The taurine released via the volume-activated transporter could be taken up again, at a later stage, via the $\mathrm{Na}^{+}$-dependent $\beta$-amino acid carrier. The observation that volume-sensitive taurine efflux is relatively temperature insensitive and that it cannot be trans-accelerated by external taurine is consistent with the pathway being a channel rather than a carrier, as suggested for volume-activated amino acid transport in other cells (Banderali \& Roy, 1992; Kirk et al. 1992; Jackson \& Strange, 1993). The efflux of glycine from rat mammary tissue explants is also increased following cell swelling (Shennan et al. 1994a). The characteristics of volume-sensitive taurine and glycine efflux are similar, suggesting that they may utilize a single pathway. The precise substrate specificity of the volume-activated pathway is not yet known.

Volume-sensitive taurine release from rat mammary tissue can be inhibited by a range of pharmacological agents (Table 3). Many of the inhibitory agents are also inhibitors of volume-activated anion channels and this has prompted the suggestion that amino acids utilize anion channels during a RVD (Banderali \& Roy, 1992; Kirk et al. 1992; Jackson \& Strange, 1993). In support of this is the finding from patch clamp studies of MDCK and glioma cells that amino acids, including taurine, can permeate volume-sensitive anion channels. However, anion-channel inhibitors are notoriously non-specific (Cabantchik \& Greger, 1992) and identity between transport systems should not be inferred only from inhibitor studies. For example, many of the inhibitors of volume-activated amino acid and anion channels also inhibit transporters as diverse as anion-exchangers, $\left(\mathrm{Na}^{+}+\mathrm{P}_{\mathrm{I}}\right)$ cotransport, $\left(\mathrm{Na}^{+}+\mathrm{I}^{-}\right)$cotransport and non-selective cation channels. Interestingly, cell swelling does not induce the release of $\mathrm{I}^{-}$, a substrate of volume-sensitive anion channels, from rat mammary explants (Shennan et al. 1994a), suggesting that volume-sensitive amino acid efflux from mammary tissue occurs at a site other than volume-sensitive anion channels.

It has also been claimed that volume-activated amino acid transport induced by cell swelling involves the anion exchanger (band 3 protein; Goldstein \& Brill, 1991). The notion that amino acids can utilize the anion exchanger is not new; Ellory et al. (1981) 

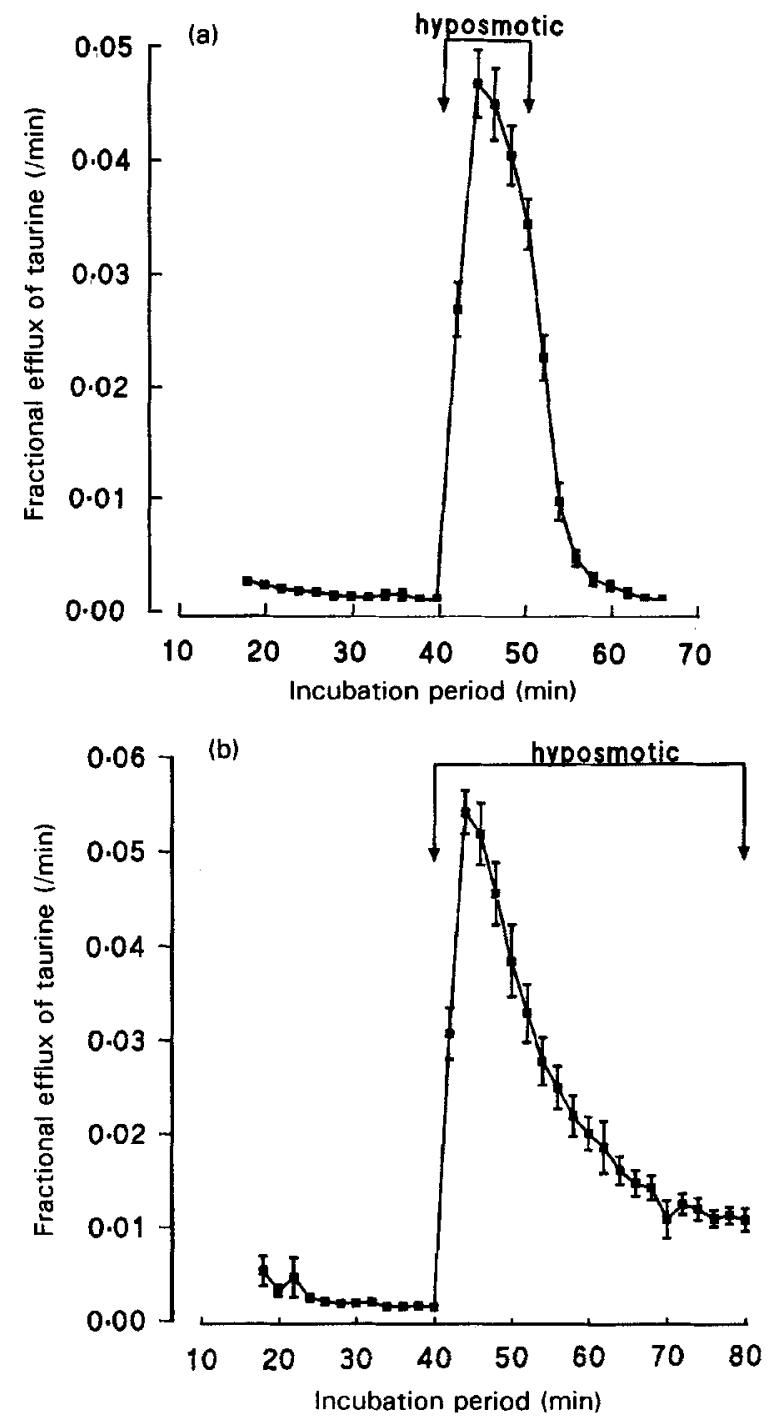

Fig. 2. The effect of a hyposmotic challenge on taurine release from lactating rat mammary tissue explants. In this set of experiments the isosmotic buffer contained (mM): $\mathrm{NaCl} 135, \mathrm{KCl} 5, \mathrm{CaCl}_{2} 2, \mathrm{MgSO}_{4} 1$, glucose 10 , Tris-3-[Nmorpholino]propanesulfonic acid 10, pH 7.4. The hyposmotic buffer was similar in composition except that the $\mathrm{NaCl}$ concentration was reduced to $55 \mathrm{mM}$. (a), Illustrates that volume-sensitive taurine release is fully reversible; (b), shows that volume-activated taurine efflux inactivates with time. Values are means with their standard errors represented by vertical bars. (From Shennan, unpublished results.)

found that glycine, under isosmotic conditions, is a substrate of the erythrocyte anion exchanger. However, the observation that the transport of sulfate, a substrate of the anion exchanger in mammary tissue (Shennan, 1989), is unaffected by cell swelling suggests that volume-activated amino acid efflux from rat mammary tissue does not use the anionexchange mechanism (Shennan et al. 1994a). The precise identity of the volume-sensitive amino acid transporter in mammary tissue remains to be identified. 
Table 3. Inhibition of volume-sensitive taurine release from mammary tissue by anion transport blockers*

(Mean values with their standard errors for the no. of experiments shown)

\begin{tabular}{|c|c|c|c|c|}
\hline \multirow[b]{2}{*}{ Inhibitor } & \multirow[b]{2}{*}{ Molarity } & \multicolumn{3}{|c|}{ Inhibition (\%) } \\
\hline & & Mean & SE & $n$ \\
\hline NPPB & $10^{-4}$ & $72 \cdot 3$ & 1.6 & 5 \\
\hline DIOA & $10^{-4}$ & 69.7 & $4 \cdot 3$ & 5 \\
\hline \multirow[t]{2}{*}{ Diiodosalicylate } & $10^{-3}$ & 96.7 & 0.3 & 3 \\
\hline & $10^{-4}$ & 61.7 & 4.8 & 4 \\
\hline Flufenamate & $10^{-4}$ & $54 \cdot 2$ & $4 \cdot 1$ & 4 \\
\hline Mefenamate & $10^{-4}$ & 39.3 & $4 \cdot 6$ & 4 \\
\hline \multirow[t]{2}{*}{ Niflumate } & $10^{-3}$ & $96 \cdot 1$ & 0.5 & 5 \\
\hline & $10^{-4}$ & 34.6 & $1 \cdot 5$ & 3 \\
\hline \multirow[t]{2}{*}{ DIDS } & $10^{-3}$ & 73.0 & $4 \cdot 7$ & 4 \\
\hline & $10^{-4}$ & $28 \cdot 6$ & 4.3 & 4 \\
\hline
\end{tabular}

NPPB, 5-nitro-2(3-phenylpropylamino)benzoic acid; DIOA, R(+)[2-n-butyl-6,7-dichloro-2-cyclopentyl-2,3-dihydro-1oxo-IH-inden-5-oxy]acetic acid; DIDS, 4,4'-diisothiocyanatostilbene-2' $2^{\prime} 2^{\prime}$-disulfonic acid.

*Tissue was transferred from an isosmotic solution (295 (SE 3) mosmol/kg) containing (mM): $\mathrm{NaCl} 135, \mathrm{KCl} 5, \mathrm{CaCl} 2$, $\mathrm{MgSO}_{4}$ 1, glucose 10, Tris-3-[N-morpholino]propanesulfonic acid 10, pH 7.4, to one made hyposmotic by reducing the $\mathrm{NaCl}$ concentration to $55 \mathrm{mM}(145$ (SE 4) mosmol/kg). When required, the drugs were present throughout the entire time course.

Cells are also capable of regulating their volume following shrinking. This is known as a volume-regulatory increase and is accomplished by activating transport systems which act to increase the intracellular osmolyte content. There is compelling evidence that $\mathrm{Na}^{+}$dependent amino acid transporters are involved in a regulatory volume increase in a variety of cell types (Hoffmann \& Simonsen, 1989; Kwon \& Handler, 1995). However, the effect of cell shrinking on the activity of mammary amino acid transport systems remains to be examined.

A thorough knowledge of (a) the systems involved in mammary cell volume regulation and (b) the factors which can change mammary cell volume in vivo is particularly desirable in light of the recent finding that mammary protein synthesis can be influenced by the cellular hydration state (Millar et al. 1996c). Increasing cell volume by a hyposmotic shock increases protein synthesis measured by following the rate of incorporation of radiolabelled leucine into trichloroacetic acid-precipitable material. In contrast, a reduction in volume induced by a hyperosmotic challenge decreases mammary protein synthesis. The activity of $\mathrm{Na}^{+}$-dependent amino acid transporters may play an important role in the regulation of the hydration state of mammary secretory cells and, thus, protein synthesis.

\section{PEPTIDE TRANSPORT BY THE MAMMARY GLAND}

The present paper would be incomplete without the mention of the possible existence of peptide carriers in mammary tissue. Studies aimed at comparing the rate of amino acid uptake and their subsequent appearance in milk have indicated that amino acids fall into three categories: (1) those that are taken up by the gland in excess of their output in milk protein, (2) those whose uptake closely matches their appearance in milk protein, (3) those whose extraction is insufficient to account for their output. The non-essential amino acids which fall into the last category are probably synthesized within the secretory cells to make up for the shortfall. However, it has been suggested that the uptake of peptides by the mammary gland may also account for the deficit. Peptide transport has been described in a 
number of cell types and several of the transporters have been cloned. A study by Backwell et al. (1994) has shown that the goat mammary gland is capable of utilizing dipeptides; thus, they observed that labelled amino acids presented to the gland as dipeptides were used for milk protein synthesis. However, this is not direct proof that the mammary gland possesses peptide carriers as the peptides could be hydrolysed before the uptake of the individual labelled amino acids. As mentioned previously there is a precedent for this: Pocius et al. (1981) have shown that glutathione can be hydrolysed and the individual amino acids taken up by bovine mammary tissue fragments.

\section{CONCLUDING REMARKS}

Although our understanding of mammary amino acid transport mechanisms is steadily improving it is evident that much more work is needed. It seems likely that future studies will focus on the regulatory aspects of mammary amino acid transport. For example, more information is needed about (a) how prolactin finely regulates individual transporters, (b) the transduction system involved in the control of transport by milk stasis and (c) the precise effect of substrate supply on the activity of the amino acid transport systems. Another area which needs to be investigated is whether growth hormone regulates mammary amino acid transport. Information is also needed about how the intracellular amino acid pool changes in response to endocrine manipulations. Moreover, the contribution of the volume-sensitive amino acid efflux system and $\mathrm{Na}^{+}$-dependent amino acid transport mechanisms to the cellular hydration state should be determined given the relationship between cell volume and mammary protein synthesis.

The authors acknowledge the support of the Scottish Office Agriculture Fisheries and Environment Department.

\section{REFERENCES}

Backwell, F. R. C., Bequette, B. J., Wilson, D., Calder, A. G., Metcalf, J. A., Wray-Cahen, D., MacRae, J. C., Beever, D. E. \& Lobley, G. E. (1994). Utilization of dipeptides by the caprine mammary gland for protein synthesis. American Journal of Physiology 267, R1-R6.

Banderali, U. \& Roy, G. (1992). Anion channels for amino acids in MDCK cells. American Joumal of Physiology 263, C1200-C1207.

Barcellos-Hoff, M. H., Aggelo, J., Ram, T. G. \& Bissell, M. J. (1989). Functional differentiation and alveolar morphogenesis of primary mammary cultures on reconstituted basement membrane. Development 105, 223235.

Barry, P. H. \& Diamond, J. M. (1984). Effects of unstirred layers on membrane phenomena. Physiological Reviews 164, 763-872.

Baumrucker, C. R. (1984). Cationic amino acid transport by bovine mammary tissue. Journal of Dairy Science 67, 2500-2506.

Baumrucker, C. R. (1985). Symposium: Nutrient uptake across the mammary gland. Amino acid transport systems in bovine mammary tissue. Journal of Dairy Science 68, 2436-2451.

Baumrucker, C. R., Pocius, P. A. \& Riss, T. L. (1981). Glutathione utilization by lactating bovine mammary secretory tissue in vitro. Biochemical Journal 198, 243-246.

Bertran, J., Werner, A., Stange, G., Markovich, D., Biber, J., Testar, X., Zorzano, A., Palacin, M. \& Murer, H. (1992). Expression of $\mathrm{Na}^{+}$-independent amino acid transport in Xenopus laevis oocytes by injection of rabbit kidney cortex mRNA. Biochemical Journal 281, 717-723.

Blatchford, D. R., Hendry, K. A. K., Turner, M. D., Burgoyne, R. D. \& Wilde, C. J. (1995). Vectorial secretion by constitutive and regulated secretory pathways in mammary epithelial cells. Epithelial and Cell Biology 4 , 8-16.

Cabantchik, Z. I. \& Greger, R. (1992). Chemical probes for anion transporters of mammalian cell membranes. American Journal of Physiology 262, C803-C827.

Calvert, D. T. \& Shennan, D. B. (1996). Evidence for an interaction between cationic and neutral amino acids at the blood-facing aspect of the lactating rat mammary epithelium. Journal of Dairy Research 63, $25-33$. 
Chamberlin, M. E. \& Strange, K. (1989). Anisosmotic cell volume regulation: a comparative view. American Journal of Physiology 257, C159-C173.

Chen, L.-H. \& Bissell, M. J. (1989). A novel regulatory mechanism for whey acidic protein gene expression. Cell Regulation 1, 45-54.

Clark, J. H., Spires, H. R. \& Davis, C. L. (1978). Uptake and metabolism of nitrogenous compounds by the lactating mammary gland. Federation Proceedings 37, 1233-1238.

Deves, R., Chavez, P. \& Boyd, C. A. R. (1992). Identification of a new transport system (y ${ }^{+} L$ ) in human erythrocytes that recognizes lysine and leucine with high affinity. Journal of Physiology 454, 491-501.

Ellory, J. C., Jones, S. E. M. \& Young, J. D. (1981). Glycine transport in human erythrocytes. Journal of Physiology 320, 403-422.

Furesz, T. C., Moe, A. J. \& Smith, C. H. (1992). Two cationic amino acid transport systems in human placental basal plasma membranes. American Journal of Physiology 261, C246-C252.

Goldstein, L. \& Brill, S. R. (1991). Volume-activated taurine efflux from skate erythrocytes: possible Band 3 involvement. American Journal of Physiology 260, R1014-R1020.

Guinard, J. \& Rulquin, H. (1994). Effect of graded levels of duodenal infusions of casein on mammary uptake in lactating cows. 2. Individual amino acids. Journal of Dairy Science 77, 3304-3315.

Guinard, J. \& Rulquin, H. (1995). Effects of graded amounts of duodenal infusions of methionine on the mammary uptake of major milk precursors in dairy cows. Journal of Dairy Science 78, 2196-2207.

Hayden, T. J. \& Smith, S. V. (1981). Effects of bromocryptine and occlusion of nipples on prolactin receptor and lactose synthesase activity in the mammary gland of the lactating rat. Journal of Endocrinology 91, $225-232$.

Hoffmann, E. K. \& Simonsen, L. O. (1989). Membrane mechanisms in volume and pH regulation in vertebrate cells. Physiological Reviews 69, 315-382.

Hollmann, K. H. (1974). Cytology and fine structure of the mammary gland. In Lactation, vol. 2, pp. 3-95 [B. L. Larson and V. R. Smith, editors]. London: Academic Press.

Hurley, W. L., Blatchford, D. R., Hendry, K. A. K. \& Wilde, C. J. (1994). Extracellular matrix and mouse mammary cell function: comparison of substrata in culture. In Vitro Tissue and Cell Biology 30A, 529-538.

Huxtable, R. J. (1992). Physiological actions of taurine. Physiological Reviews 72, 101-163.

Jackson, P. S. \& Strange, K. (1993). Volume-sensitive anion channels mediate swelling-activated inositol and taurine efflux. American Journal of Physiology 265, C1489-C1500.

Jessen, H. (1994). Taurine and B-alanine transport in an established human kidney cell line derived from the proximal tubule. Biochimica et Biophysica Acta 1194, 44-52.

Kanai, Y. \& Hediger, M. A. (1992). Primary structure and functional characterization of a high-affinity glutamate transporter. Nature 360, 467-471.

Kanai, Y., Smith, C. R. \& Hediger, M. A. (1994). A new family of neurotransmitter transporters: the high affinity glutamate transporters. FASEB Journal 8, 1450-1459.

Kinne, R. K. H. (1993). The role of organic osmolytes in osmoregulation: From bacteria to mammals. Journal of Experimental Zoology 265, 346-355.

Kirk, K., Ellory, J. C. \& Young, J. D. (1992). Transport of organic substrates via a volume-activated channel. Journal of Biological Chemistry 267, 23475-23478.

Kwon, H. M. \& Handler, J. S. (1995). Cell volume regulated transporters of compatible osmolytes. Current Opinion in Cell Biology 131, 465-471.

Lang, F., Ritter, M., Volkl, H. \& Haussinger, D. (1993). The biological significance of cell volume. Renal Physiology and Biochemistry 16, 48-65.

Linzell, J. L. \& Peaker, M. (1971). Mechanism of milk secretion. Physiological Reviews 51, 564-597.

Mepham, T. B. (1982). Amino acid utilization by lactating mammary gland. Journal of Dairy Science 65, 287 298.

Mepham, T. B., Overthrow, J. I. \& Short, A. H. (1985). Epithelial cell entry and exit competition amongst amino acids in the isolated perfused lactating mammary gland of guinea pig. In Carrier Mediated Transport of Solutes from Blood to Tissue, pp. 369-372 [D. L. Yudilevich and G. E. Mann, editors]. London: Longman.

Metcalf, J. A., Sutton, J. D., Cockburn, J. E., Napper, D. J. \& Beever, D. E. (1991). The influence of insulin and amino acid supply on amino acid uptake by the lactating bovine mammary gland. Journal of Dairy Science 74, $3412-3420$.

Millar, I. D., Calvert, D. T., Lomax, M. A. \& Shennan, D. B. (1996a). The mechanism of L-glutamate transport by lactating rat mammary tissue. Biochimica et Biophysica Acta 1282, 200-206.

Millar, I. D., Calvert, D. T., Lomax, M. A. \& Shennan, D. B. (1996b). Interaction between anionic amino acids and the mammary tissue ( $\mathrm{Na}^{+}$-glutamate) cotransporter. Biochemical Society Transactions 24, S333.

Millar, I. D., Lomax, M. A. \& Shennan, D. B. (1996c). Mammary tissue protein synthesis is regulated by cell volume. Biochemical Society Transactions 24, S335.

Neville, M. C., Lobitz, C. J., Ripoll, E. A. \& Tinney, C. (1980). The sites of $\alpha$-aminoisobutyric acid uptake in normal mammary gland and ascites tumor cells. Journal of Biological Chemistry 255, 7311-7316.

Pines, G., Danbolt, N. C., Bjoras, M., Zhang, Y., Bendahan, A., Eide, L., Koepsell, H., Storm-Mathisen, J., Seeberg, E. \& Kanner, B. L. (1992). Cloning and expression of a rat brain L-glutamate transporter. Nature 360, 464-467. 
Pocius, P. A., Clark, J. H. \& Baumrucker, C. R. (1981). Glutathione in bovine blood: possible source of amino acids for milk protein synthesis. Journal of Dairy Science 64, 1551-1554.

Rassin, D. K., Sturman, J. A. \& Gaull, G. E. (1978). Taurine and other free amino acids in milk of man and other species. Early Human Development 2, 1-13.

Rillema, J. A., Golden, K. \& Jenkins, M. A. (1992). Effects of prolactin on AIB uptake in mouse mammary gland explants. American Journal of Physiology 262, E402-E405.

Sarkadi, B. \& Parker, J. C. (1991). Activation of ion transport pathways by changes in cell volume. Biochimica et Biophysica Acta 1071, 404-427.

Shennan, D. B. (1989). A study of sulphate transport by lactating rat mammary tissue; evidence for anion exchange. Comparative Biochemistry and Physiology 92A, 145-150.

Shennan, D. B. (1990). Mini review: mechanisms of mammary gland ion transport. Comparative Biochemistry and Physiology 97A, 317-324.

Shennan, D. B. (1992). $\mathrm{K}^{+}$and $\mathrm{Cl}^{-}$transport by mammary secretory cell apical membrane vesicles isolated from milk. Journal of Dairy Research 59, 339-348.

Shennan, D. B. (1995). Identification of a high affinity taurine transporter which is not dependent on chloride. Bioscience Reports 15, 231-239.

Shennan, D. B. \& McNeillie, S. A. (1994a). Characteristics of $\alpha$-aminoisobutyric acid transport by the lactating rat mammary gland. Joumal of Dairy Research 61, 9-19.

Shennan, D. B. \& McNeillie, S. A. (1994b). High affinity $\left(\mathrm{Na}^{+}+\mathrm{Cl}^{-}\right)$-dependent taurine transport by lactating mammary tissue. Journal of Dairy Research 61, 335-343.

Shennan, D. B. \& McNeillie, S. A. (1994c). Milk accumulation down regulates amino acid uptake via systems A and $\mathrm{L}$ by lactating mammary tissue. Hormone and Metabolic Research 26, 611.

Shennan, D. B., McNeillie, S. A. \& Curran, D. E. (1994a). The effect of a hyposmotic shock on amino acid efflux from lactating rat mammary tissue: stimulation of taurine and glycine efflux via a pathway distinct from anion exchange and volume-activated anion channels. Experimental Physiology 79, 797-808.

Shennan, D. B., McNeillie, S. A., Jamieson, E. A. \& Calvert, D. T. (1994b). Lysine transport in lactating rat mammary tissue: evidence for an interaction between cationic and neutral amino acids. Acta Physiologica Scandinavica 151, 461-466.

Shennan, D. B. \& Madon, R. J. (1991). An effect of prolactin on $\mathbf{K}^{+}$uptake by lactating rat mammary tissue. Hormone and Metabolic Research 23, 293-294.

Storck, T., Schulte, S., Hofmann, K. \& Stoffel, W. (1992). Structure, expression and functional analysis of a $\mathrm{Na}^{+}$-dependent glutamate aspartate transporter from rat brain. Proceedings of the National Academy of Sciences USA 89, 10959-10995.

Sturman, J. A., Rassin, D. K. \& Gaull, G. E. (1977). Taurine in developing rat brain: transfer of $\left[{ }^{35}\right.$ S]taurine to pups via the milk. Pediatric Research 11, 28-33.

Van Winkle, L. J., Campione, A. L. \& Gorman, J. M. (1988). Na ${ }^{+}$-independent transport of basic and zwitterionic amino acids in mouse blastocyst by a shared system and by processes which distinguish between these substrates. Journal of Biological Chemistry 263, 3150-3163.

Vina, J., Puertes, I. R., Saez, G. T. \& Vina, J. R. (1981a). Role of prolactin in amino acid uptake by the lactating mammary gland of the rat. FEBS Letters 126, 250-252.

Vina, J. R., Puertes, I. R. \& Vina, J. (1981b). Effect of premature weaning of amino acid uptake by the mammary gland of lactating rats. Biochemical Journal 200, 705-708.

Wilde, C. J. \& Peaker, M. (1990). Autocrine control in milk secretion. Journal of Agricultural Science, Cambridge 114, 235-238.

Yudilevich, D. L. \& Mann, G. E. (1982). Unidirectional uptake of substrates at the blood side of secretory epithelia: Stomach, salivary gland, pancreas. Federation Proceedings 41, 3045-3053.

Yudilevich, D. L. \& Sweiry, J. (1985). Transport of amino acids in the placenta. Biochimica et Biophysica Acta 822, 169-201. 